\title{
The overview of hypertension patient and family support
}

\author{
Lintang Raspaty Gandhi ${ }^{1}$, Yuliarti ${ }^{2}$ \\ ${ }^{1,2}$ Students of Nursing Study Program, Faculty of Health Sciences, University of Muhammadiyah Purwokerto, Indonesia
}

\section{ARTICLE INFO}

\section{Article history:}

Received: August 9, 2020

Revised: August 20, 2020

Accepted: August 30, 2020

Keywords:

Family support, hypertension.

\begin{abstract}
Hypertension is a condition in which systolic blood pressure $\geq 140 \mathrm{mmHg}$ and diastolic pressure $\geq 90 \mathrm{mmHg}$ at two measurements with an interval of five minutes in a resting state. From the data reports retrieved from community health center for 2018 - 2019 there is an increase in the number of cases of hypertension sufferers. The research design used was qualitative with a phenomenological approach, This research uses interview, observation, and documentation techniques. The results of the study were the youngest informants in this study were 21 years and the oldest was 62 years. The youngest age of hypertensive patients is 50 years and the oldest is 70 years. Patients still lack informational support, namely families rarely explain the importance of taking medication and how to take medicine correctly, giving positive appreciation to informants is good, care support is good, namely the family has delivered and accompanied patients to health services, the family has provided emotional support such as providing enthusiasm, love, and encouragement to live life.In conclusion patients with hypertension are $\geq 40$ years of age. Of all the family support that is provided, there is one less good support, namely informational support.
\end{abstract}

This work is licensed under a Creative Commons Attribution 4.0 International License.

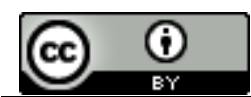

\section{Corresponding Author:}

Lintang Raspaty Gandhi,

Students of Nursing Study Program,

Faculty of Health Sciences,

Universitas Muhammadiyah Purwokerto, Indonesia

\section{INTRODUCTION}

The Hypertension is a condition in which systolic blood pressure $\geq 140 \mathrm{mmHg}$ and diastolic pressure $\geq 90 \mathrm{mmHg}$ at two measurements with an interval of five minutes in a resting state. Therefore hypertension is said to be the silentkiller [1]. Data from the community health center I Sokaraja report in 2018 Hypertension was ranked 3rd in the top 10 diseases with a total of 1705 cases. Report data for the January-August 2019 Period Hypertension increased to second place in the top 10 diseases with the total number of 1532 people. Based on the results of a preliminary research on hypertensive patients at community health center I Sokaraja, it was stated that family support was low because there were several factors, namely a lack of awareness to visit the community health center, a lack of motivation to take medication and a lack of discipline to maintain healthy dietary behaviour.

\section{RESEARCH METHOD}

Explaining The research design used was qualitative with a phenomenological approach. The research was conducted in June 2020 at community health center 1 Sokaraja with 10 respondents involved using data saturation. This study used interview as data collection techniques, observation, and documentation. Data was collected using purposive sampling based on inclusion and exclusion criteria with data analysis techniques, namely data collection, data reduction and data presentation.

\section{RESULTS AND DISCUSSIONS}

\subsection{Overview of Informational Support}

In their supportive role on their family member who suffer sickness, some of the informants have already put their effort but unfortunately there has been many cases that some others has not yet made effort to 
share information of the importance of medication. Here is the result of the interview:

"My family never give any explanation to me, I am the only one who think who important is to take medication. Yes...There is difference when I take medication" (R1-Tn.D-57).

The family does not provide information about taking the right medicine, because usually it has been explained directly from the health service, but there are some families who also explain, besides that, no one uses drugs other than from the health center such as herbal medicine, only consuming herbal jamu such as turmeric, cucumber and onion to relieve the symtom. The result of interview :

"He just asked" did you already take the medicine"or warning whether he has drunk the medicine or npt"? (R1-Tn.D-57).

“Amlodipine 5 mg” (R1-Tn.D-57).

"Take it twice in the morning and at night" (R1-Tn.D-57).

The factors that cause hypertensive patients to be less adherent to treatment are a lack of knowledge about the benefits of treatment being carried out. There is lack of information provided to patients from family or medical personnel, fear factors and a negative picture of taking anti-hypertensive drugs and patient dissatisfaction due to the length of the treatment program that must be carried out. From this theory, it can be inferred that the level of education background of patient or his family will greatly affect the health condition because usually people with higher education tend to be more aware in seeking knowledge and information.

Meanwhile, informational support from the family such as reminder to maintain healthy diet and regular exercise. As follows :

"Cut off oily food and food with high salt content, just that, If you carve, eat occasionally..."(R1-Tn.D-57)." "do a light exercise like walking around the neighboorhood ."(R1-Tn.D-57)."

"Reduce consumtion of coconut milk and oily food except fried chicken and duck hahaha.." (R2-Ny.K-62).

From the results of the research, the researcher got insufficient informational support that because all respondents still did not provide an explanation of the importance of taking medication, the patient was able to reduce the food that had to be avoided but when he saw the food he wanted, he still ate and did not exercise regularly.

Explains that the effect of salt intake on the emergence of hypertension occurs through an increase in plasma volume, cardiac output and blood pressure [2]. Stating that by limiting fat consumption is done so that cholesterol in the blood is not high. This is in line with Thiyyaroobini friendly research that most respondents have medication adherence and have low knowledge.

\subsection{Overview of Achievement Support}

There are some who have given it and there are still those who have not given praise and support or support to patients. Every family has their own way of how to give it. The following are the results of the interview:

"Did not give praise, even sometimes he said he was healed, so you don't need to take medicine, no people who live healthily want to take medication continuously."(R1-Tn.D-57).

"My child rarely give any support, just reminds me to take medicine, because I only live with the child, the mother is already gone"(R1-Tn.D-57).

From the results of this research that the support for appreciation was sufficient from 10 informants, there were 7 informants who had received positive support from the family, namely giving praise, support, advice and encouragement to get well soon.

\subsection{Overview of Instrumental Support or Care}

In an effort to help family members who are sick, there are several families who accompany them when they go to health services but there are also patients who leave alone on the grounds that no one is accompanying them because the family is busy for work:

"I have never been accompanied to a health service.(R1-Tn.D-57)."

The function of care is carried out by providing care to family members in the form of prevention to caring for a sick family [3]. In accordance with the results of the research that the researchers got, namely the instrumental support or care was good from 10 informants, there were 8 informants who had been accompanied when they went to health care providers, but there were still 2 who had not been accompanied by their families because they did not care and some were because they were busy.

\subsection{Overview of Emotional Support}

All families and patients accept all the conditions they are facing and feel what the patient feels. The family also encourages patients not to give up. Following are the results of the interview:

"Yes, just be patient, this is a disease, trial from Allah, how else, hehe (R1-Tn.D-57)."

Of the 10 family informants, they have provided emotional support, although it is still lacking, but 
they have given it as much as possible. Starting from accepting all the conditions that are being faced, the family maintains feelings, the family provides encouragement so that the patient does not give up on living his life and this is in accordance with emotional support gives individuals a feeling of comfort, feels loved when experiencing depression, assistance in form of enthusiasm, empathy, trust, attention so that the individual who receives it feels valuable.

According to Nihayati [2] that family can reduce pain and speed up the recovery process from an illness by providing support to family members who are sick, because family members who are sick need encouragement from outside themselves to maintain and help improve their health. Reveals that family can act as an emotional support for patients. Family can be a place for patients to share what they are facing. [4]

\section{CONCLUSION}

Patients with hypertension are aged $\geq 40$ years old. Of all the family support provided, there is still one less good support, namely informational support.

\section{REFERENCES}

[1] Karo, "Hipertensi adalah Masalah Kesehatan Masyarakat," in Penyakit Kardiovaskular (PKV) 5 Rahasia, Jakarta, Badan Penerbit Fakultas Kedokteran Universitas Indonesia, 2012, pp. 235-248.

[2] Nihayati, "Dukungan sosial pada penyandang HIV/AIDS dewasa," Universitas Muhammadiyah, 2012.

[3] Evarina, "Pengaruh dukungan keluarga terhadap program pengobatan pasien HIV/AIDS diposyandu RSUP Haji Adam Malik Medan.," Medan, 2011.

[4] Y. Mangendai, S. Rompas and R. S. Hamel, "Faktor-Faktor Yang Berhubungan Dengan Kepatuhan Berobat Pada Pasien Hipertensi Di Puskesmas Ranotana Weru.," E-Journal Keperawatan, vol. 5, 2017. 